\title{
Do farmers rapidly adapt to past growing conditions by sowing different proportions of early and late maturing cereals and cultivars?
}

\author{
Pirjo Peltonen-Sainio ${ }^{1 *}$, Lauri Jauhiainen ${ }^{1}$, Jarkko K. Niemi ${ }^{2}$, Kaija Hakala ${ }^{1}$, Timo Sipiläinen ${ }^{3}$ \\ ${ }^{1}$ MTT Agrifood Research Finland, Plant Production Research, FI-31600 Jokioinen, Finland \\ ${ }^{2}$ MTT Agrifood Research Finland, Economic Research, Latokartanonkaari 9, Fl-00790 Helsinki, Finland \\ ${ }^{3}$ University of Helsinki, Department of Production Economics and Farm Management, Latokartanonkaari 9, PL 27, FI-00014 \\ University of Helsinki, Finland \\ *e-mail pirjo.peltonen-sainio@mtt.fi
}

\begin{abstract}
In the short growing season of the northernmost European growing conditions, farmers are increasingly interested in expanding cultivation of later maturing crops at the expense of early maturing ones with lower yields. In this study we aimed to assess how the switching between spring cereals that differ in earliness was associated with different external factors. This was tested using unique datasets for regional cropping areas and cultivar use for the last 15 years. Early maturing barley was favored at the expense of later maturing wheat when a high number of days to crop maturity was required in the preceding year. In contrast, farmers reduced the barley area when a high number of cumulated degree days was required for a crop to mature in the previous year. A shift was recorded from early to late maturing cultivars. This study indicated that despite limited opportunities for farmers to alter land use, they readily responded to past conditions and used the knowledge gained for decision-making to reduce risk. This is a valuable operative model for studying adaptation to opportunities and constraints induced by climate change.
\end{abstract}

Key words: barley, climate, cultivar, oat, weather variation, wheat, yield

\section{Introduction}

Finland is the world's northernmost region where grain crops are widely grown (Peltonen-Sainio et al. 2009a). Current grain crop production takes place on $\sim 1.1$ million hectares. At high latitudes, long days markedly enhance pre-anthesis development rate of cereals (Peltonen-Sainio and Rajala 2007), enabling timely harvest. Climatic constraints, however, cause substantial production uncertainty (Peltonen-Sainio et al. 2009b, Himanen et al. 2012, Peltonen-Sainio and Niemi 2012). In addition to the short growing season, northern conditions are characterized by harsh and variable winter conditions, a short period for successful spring sowing after snow melt and soil drying, early summer drought, and rapid changes at the end of summer towards non-growth-favoring autumn conditions (Mukula and Rantanen 1987, Peltonen-Sainio et al. 2009a, 2011a, 2011b). When comprehensive climate data from recent decades were analyzed, the Boreal zone, represented by Finland as compared to with other European environmental zones, was found to have at remarkably fewer suitable days for spring sowing, half the growth-favoring days, significantly higher risks of late spring frosts and more growth-limiting days in mid-summer (Trnka et al. 2011).

Growing degree-days required by a crop to mature represent the most critical characteristic determining yield potential, and thus regional prevalence of each crop. Spring sown cereals, barley (Hordeum vulgare L.), oat (Avena sativa L.) and wheat (Triticum aestivum L.) dominate southern regions, where turnip rape (Brassica rapa L.), oilseed rape (Brassica napus L.), and more occasionally faba bean (Vicia faba L.) and pea (Pisum sativum L.), as minor crops, add diversity to crop rotations. By contrast, dairy-oriented production and grasslands are concentrated in central and northern Finland, where also barley and oat are widely grown for feed.

The crops grown in regions between $60^{\circ} \mathrm{N}$ and $65^{\circ} \mathrm{N}$ are considered to be sufficiently adapted to the prevailing conditions, but plant breeding continues to develop cultivars that are well adapted to meet local growing conditions, especially regarding length of the growing season (Peltonen-Sainio et al. 2009c, 2009d). Despite local initiatives to improve adaptive capacity through crop and cultivar selection, fluctuating and changing weather conditions recurrently induce variation in yields (Lobell and Field 2007, Lobell et al. 2007, Peltonen-Sainio et al. 2010, Himanen et al. 2012). Hakala et al. (2012) demonstrated variability in barley cultivars adapted to northern European growing conditions in their response to climatic constraints during different phenological phases. However, 
many European "supranational" cultivars are also grown in Finland in addition to local breeds because they are of the quality required for specific processing (e.g., in malting industry). Thereby, farmers have access to cereal cultivars that may vary considerably in their response to conditions due to differences in adaptive capacity, i.e. capacity to cope with the constraints of northern agro-ecosystems. Characteristics such as intensity of cropping, farm size and land use, as well as socio-economic factors contribute to sensitivity to climate-induced yield variability (Reidsma et al. 2010, Himanen et al. 2012).

Because of the northern location and fluctuating weather conditions, Finland represents an interesting case to study how farmers respond to past growing conditions. This may provide insight into farmers' ability to adapt to changing climate. A recent study indicated that farmers responded to climate warming by starting to sow earlier in the spring, representing an example of farmer readiness to adapt to changes in conditions (Kaukoranta and Hakala 2008). Another example demonstrated that the severity of winter damage in any one year was associated negatively with area sown to winter wheat in the following year (Peltonen-Sainio et al. 2011a).

In this study we hypothesize that farmers may improve cultivation choices by learning from weather, yield and other observations they make. While doing so, farmers may: a) adhere to locally best adapted crops and cultivars because risky choices may jeopardize yields and income, $b$ ) adapt cultivation according to observed conditions to benefit from higher yields that use of later maturing crops and cultivars offer, or to avoid effects of production uncertainty that they have experienced, or c) consider that weather and yield risks are only of marginal importance when compared with economic incentives and risks due to changes in public policies and markets.

\section{Material and methods}

Spring barley, oat and wheat were used as model crops because they are most commonly grown, on approximately 0.50 of arable land in Finland. They also differ both between species and among cultivars in growth duration (Table 1) and represent differences in likelihood of crop failure (Peltonen-Sainio and Niemi 2012). Changes in cereal and input prices were analyzed to determine the extent of association with changes in farmer's crop priorities and field use.

Table 1. The range among early and late maturing barley, oat and wheat cultivars in duration of major growth phases (days) and the corresponding cumulated degree days $\left({ }^{\circ} \mathrm{Cd}\right)$. Data from MTT Official Variety Trials for 1985-2009. Cultivars with $\geq 13$ records were included in the comparisons. The total numbers of cultivars were 214, 132 and 111 for barley, oat and wheat, respectively.

\begin{tabular}{|c|c|c|c|c|}
\hline \multirow{2}{*}{$\begin{array}{l}\text { Crop and } \\
\text { Major growth phase }\end{array}$} & \multicolumn{2}{|c|}{ Duration in days } & \multicolumn{2}{|c|}{ Cumulated degree days $\left({ }^{\circ} \mathrm{Cd}\right)$} \\
\hline & Early maturing & Late maturing & Early maturing & Late maturing \\
\hline \multicolumn{5}{|l|}{ Barley: } \\
\hline Sowing to heading & $48-54$ & $53-62$ & $376-461$ & $424-529$ \\
\hline Heading to maturity & $34-42$ & $37-46$ & $419-492$ & $410-532$ \\
\hline Sowing to maturity & $83-91$ & 96-102 & $784-866$ & $913-961$ \\
\hline \multicolumn{5}{|l|}{ Oat: } \\
\hline Sowing to heading & $51-58$ & $53-59$ & $401-492$ & $438-509$ \\
\hline Heading to maturity & $38-46$ & $46-51$ & $450-504$ & $495-568$ \\
\hline Sowing to maturity & $91-98$ & $102-106$ & $872-921$ & $952-991$ \\
\hline \multicolumn{5}{|l|}{ Wheat: } \\
\hline Sowing to heading & $51-56$ & $53-59$ & $391-449$ & $404-485$ \\
\hline Heading to maturity & $45-49$ & $47-53$ & $532-580$ & $545-627$ \\
\hline Sowing to maturity & $96-102$ & $104-110$ & $932-973$ & $990-1050$ \\
\hline
\end{tabular}




\section{Datasets}

Regional datasets from Tike, the Information Centre of the Ministry of Agriculture and Forestry, on cultivation areas of spring barley, oat and wheat were used for the period of 1995-2009 to identify annual shifts in cropping areas. Data comprising cropping areas of the spring cereals were used for assessing both the entire country and individual regions. The southern region comprised four counties (Uusimaa, Itä-Uusimaa, Varsinais-Suomi and Kanta-Häme) and the dairy-oriented north-central production region four additional northern counties (Pohjois-Karjala, Pohjois-Savo, Kainuu and Pohjois-Pohjanmaa) (Fig. 1). The remaining counties were treated as a single entity "other regions", and Lapland was omitted as non-agricultural area. The southern region represents the prime cereal production area, which contributes $0.68,0.30$ and 0.20 to the total wheat, barley and oat cultivation area respectively. The corresponding numbers for the dairy region are $0.03,0.18$ and 0.15 . The case regions thus represent substantial differences in frequencies of different cereal species and risks related to their production (Himanen et al. 2012, Peltonen-Sainio and Niemi 2012).

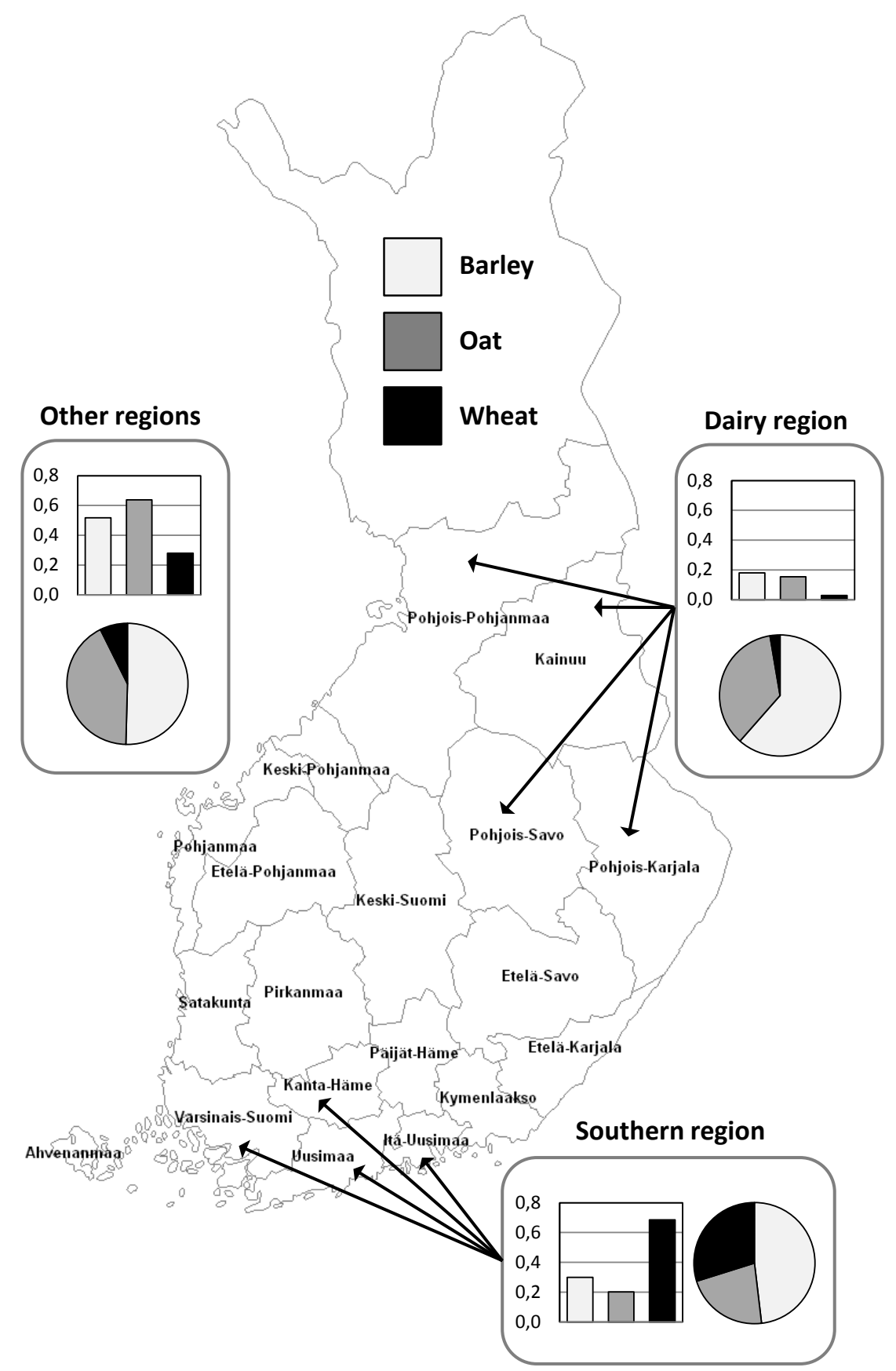

Fig. 1. Spring barley, oat and wheat cultivation area as a proportion of their total national (bar charts) and regional production area (pie charts) shown for the southern (cereal production) region and the north-central (dairy-oriented) region, indicated by arrows, and other regions (excluding Lapland). Data from Tike, Information Centre of the Ministry of Agriculture and Forestry. 
Regional datasets from Tike were used to record shifts in land use for different cereal species and cultivars. In addition, MTT Official Variety Trial datasets (Kangas et al. 2010) were used to assess possible drivers for recorded switches among barley, oat and wheat cultivars differing in earliness (Table 1) and thereby responsiveness for risks including lodging, delayed harvests and yield and quality losses. The MTT Official Variety Trial data included 488 spring barley, oat and wheat trials from 15 experimental sites for the period 1995-2009. Number of days from sowing (ZGSO0, Zadoks et al. 1974) to yellow ripeness (ZGS92) for barley (model crop as grown widely in Finland) was used for general characterization of favorability of growing season. A high number of days from sowing to ripeness often associates with cool growing conditions, which can result in harvest.

Additional climate datasets from the Finnish Meteorological Institute were used for 1995-2009 to characterize differences between years in conditions often associated with higher risks to yield and quality losses or with those that could favor growth and harvest. Climate datasets, and sowing and yellow ripening dates (determined from MTT Official Variety Trials), were used to calculate two critical weather conditions for each growing season: cumulated degree days $\left({ }^{\circ} \mathrm{Cd}\right)$ from onset of thermal growing season to $4^{\text {th }}$ September, and accumulated precipitation $(\mathrm{mm})$ in late summer, from $1^{\text {st }}$ August to 4 September. A high number of cumulated degree days generally indicates high likelihood of successful harvest and high quality yield, although elevated temperatures can also reduce yield (Peltonen-Sainio et al. 2011b, Rötter et al. 2011, Hakala et al. 2012). Elevated accumulated precipitation during late summer and at harvest results in lodging, delayed maturation of grains, quality deterioration and may also be associated with yield losses (Peltonen-Sainio et al. 2009a).

Information on monthly and annual price changes for cereals (Official Statistics of Finland 2012a) and the most important inputs (Official Statistics of Finland 2012b) were obtained from Statistics Finland. They were collated from price indices for different base years because several observations were missing from some time series. The data covered annual price indices for the most important input and outputs for the study period. Price indices for fertilizers and land improvement ingredients were used to indicate changes in major production costs. Output prices included price indices for wheat, barley and oat. Figures 2 and 3 illustrate the monthly development of cereal and input prices over the study period. Monthly prices for wheat, barley and oat were approached from different perspectives and by using different periods for examination before analyzing their association with farmer willingness to switch crops. Prices from September to December were assumed to be the most relevant for crop selection. Several other periods were used but results for prices and crop selection remained consistent.

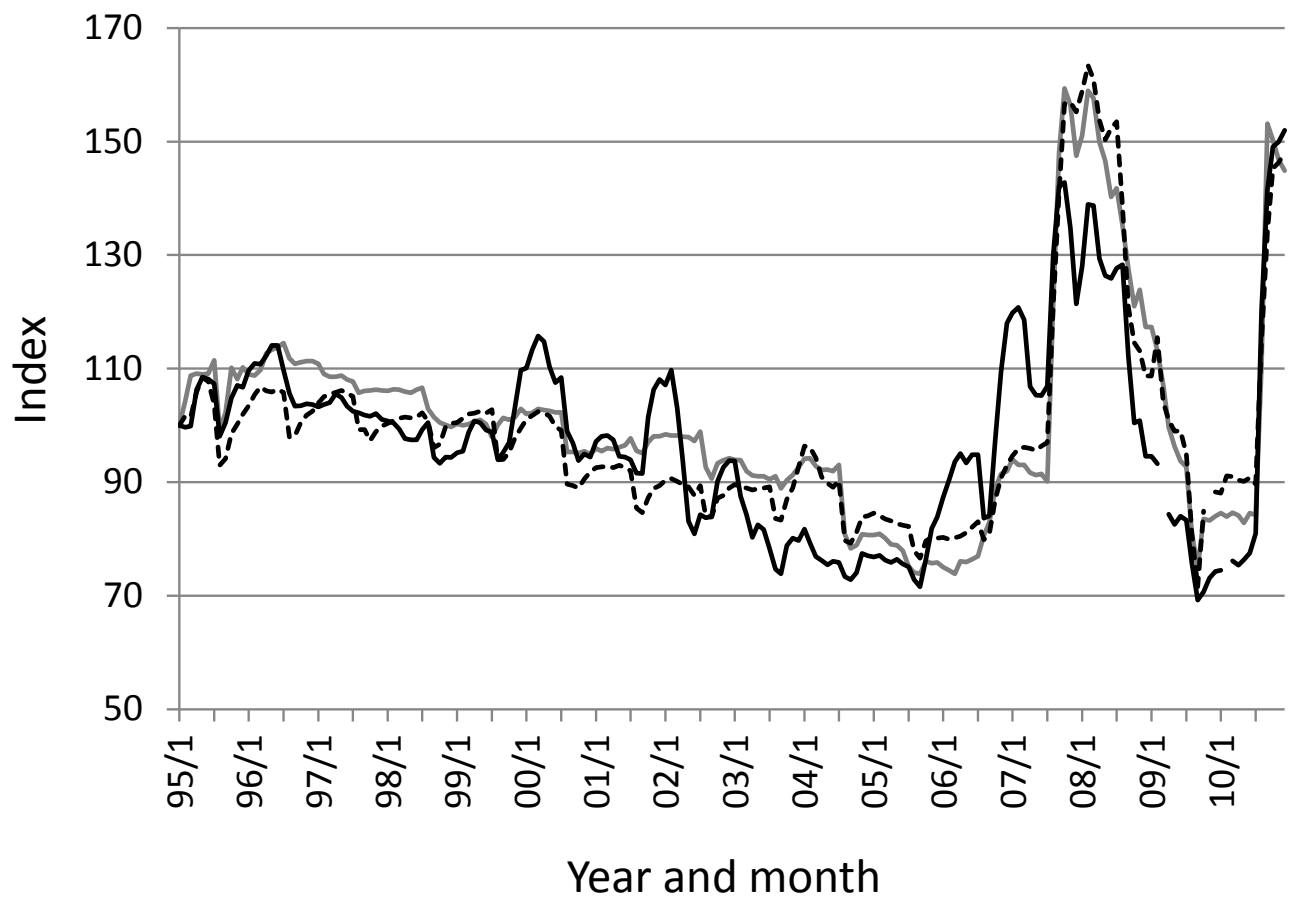

Fig. 2. Changes in cereal price indices between 1995-2010 (January 1995 considered as 100). Black dashed line represents barley, black solid line oat and grey solid line wheat. Data from Official Statistics of Finland (2012a). 


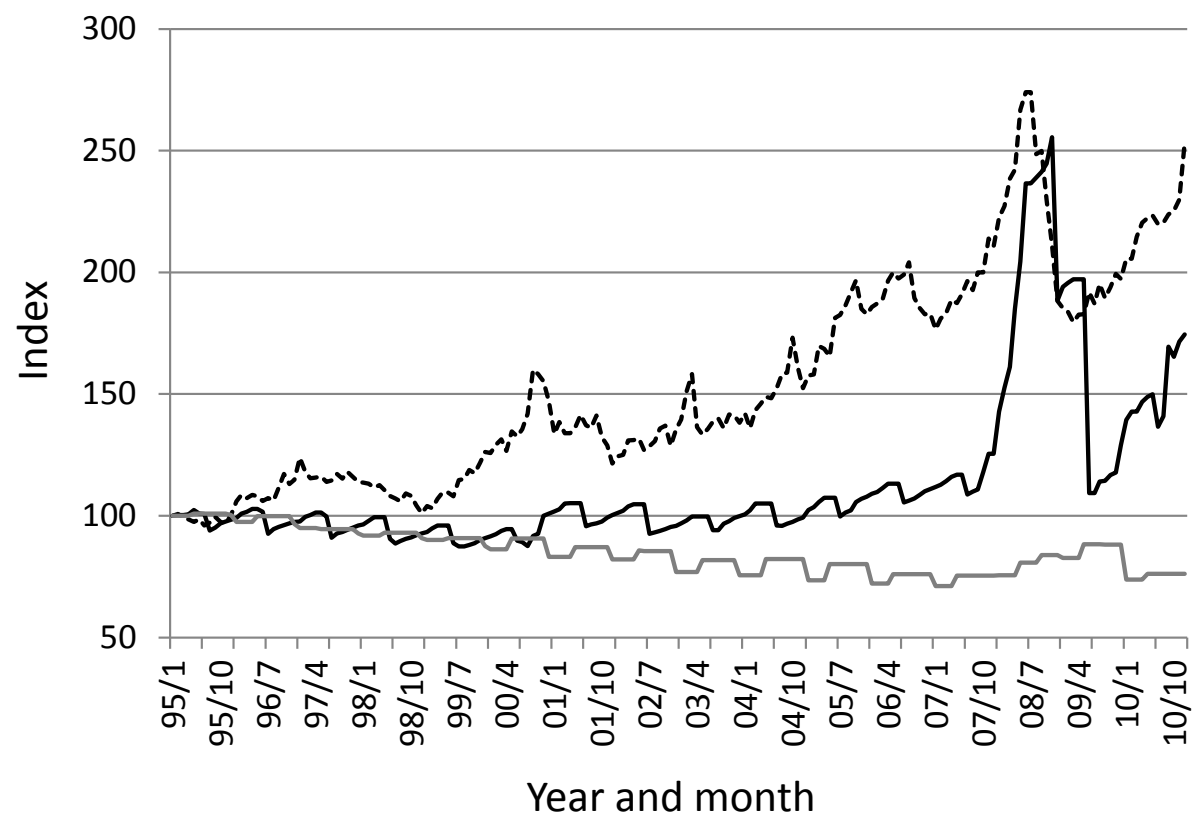

Fig. 3. Changes in input price indices between 1995-2010 (January 1995 considered as 100). Black dashed line represents energy, black solid line fertilizers, lime and other soil improvers and grey solid line herbicides and pesticides. Data from Official Statistics of Finland (2012b).

\section{Statistical analyses}

Data for the three crops were analyzed separately. Analyses were done for the entire country and separately for the cereal and the dairy-oriented production regions. Spring wheat was not included in the analysis of the dairy production region because of its negligible cultivation area. Correlation analysis was used to test relationships between relative change in cultivation area (e.g. change in relative cultivation area of barley between 2000 and 2001 ) and other variables, including growing time (days from sowing to yellow ripeness), cumulated degree days $\left({ }^{\circ} \mathrm{Cd}\right.$, from onset of thermal growing season to 4 of September) and accumulated precipitation ( $\mathrm{mm}$, during grainfilling and harvest period) of the previous growing season, as well as differences in the weather parameters between the previous two seasons (e.g. between years 1999 and 2000 in accumulated precipitation compared with cultivation area for 2001). Relative prices of crops and change in relative prices were also tested. Analysis of covariance was used to test all variables together. The dependent variable was relative change in cultivation area and independent variables were the most significant variables in the correlation analysis. SAS-software was used for statistical analyses.

MTT Official Variety Trial datasets were used to estimate growing time of each cultivar. A mixed model with a REML (restricted maximum likelihood) estimation method was used and the model included cultivar as a fixed effect and experimental site, year and their interaction as random effects. Estimates for cultivars were aggregated with datasets of TIKE to calculate average growing time for all region-by-year combinations. Relationships between changes in average growing times and other variables were tested as for the analysis of relative change in cultivated area of crops.

\section{Results and discussion}

In addition to annual fluctuations in cropping areas of selected spring cereals, we recorded gradual increases in wheat area and slight decreases in barley and oat areas during the 15 year study period (Fig. 4). In general, there has been a gradual shift towards later maturing barley cultivars (by 2-3 days) in the southern region and northcentral region (Fig. 5). In the southern region use of later maturing cultivars was also recorded for wheat and in some specific southern counties for oat (about one day later maturing cultivars in both cases). Gradual increases in later maturing cultivars of barley and wheat may partly hinder identification of season-to-season responses by farmers to experienced conditions. 

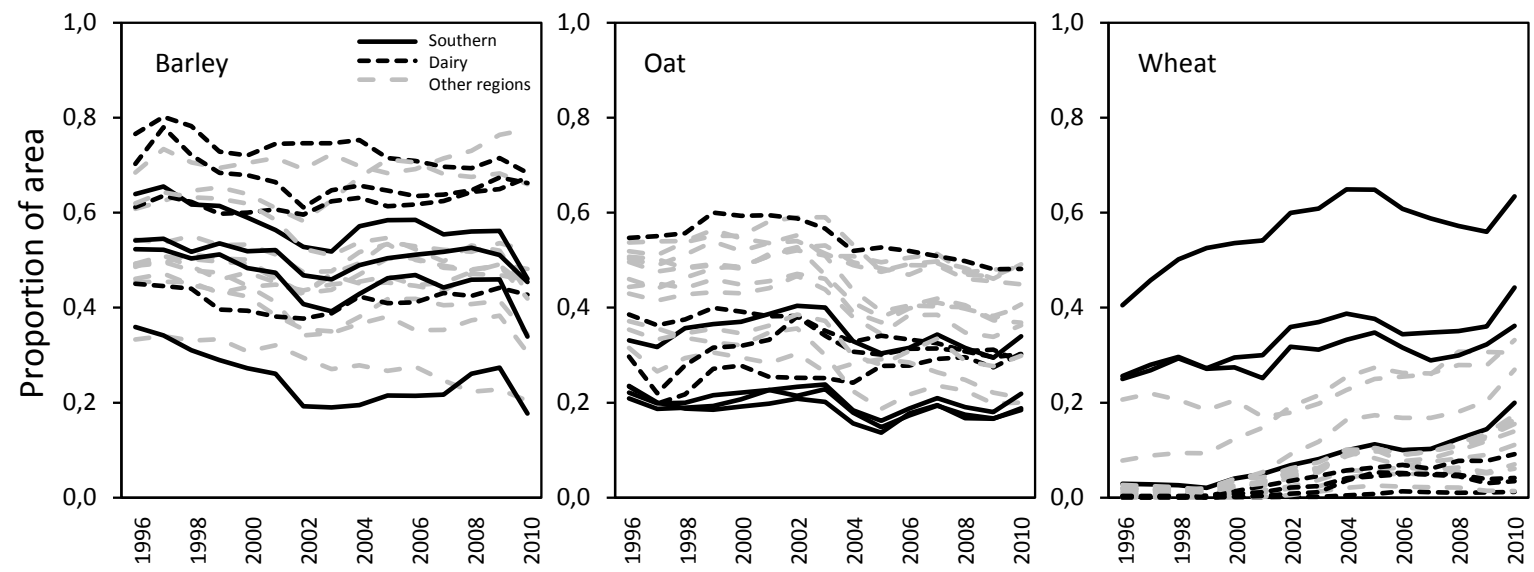

Fig. 4. Barley, oat and wheat area as a proportion of total spring cereal area in 1996-2010 for different regions representing southern production regions, north-central (dairy-oriented) production regions and other regions (excluding Lapland). Similar line types indicate sub-regions within southern, dairy or other regions.
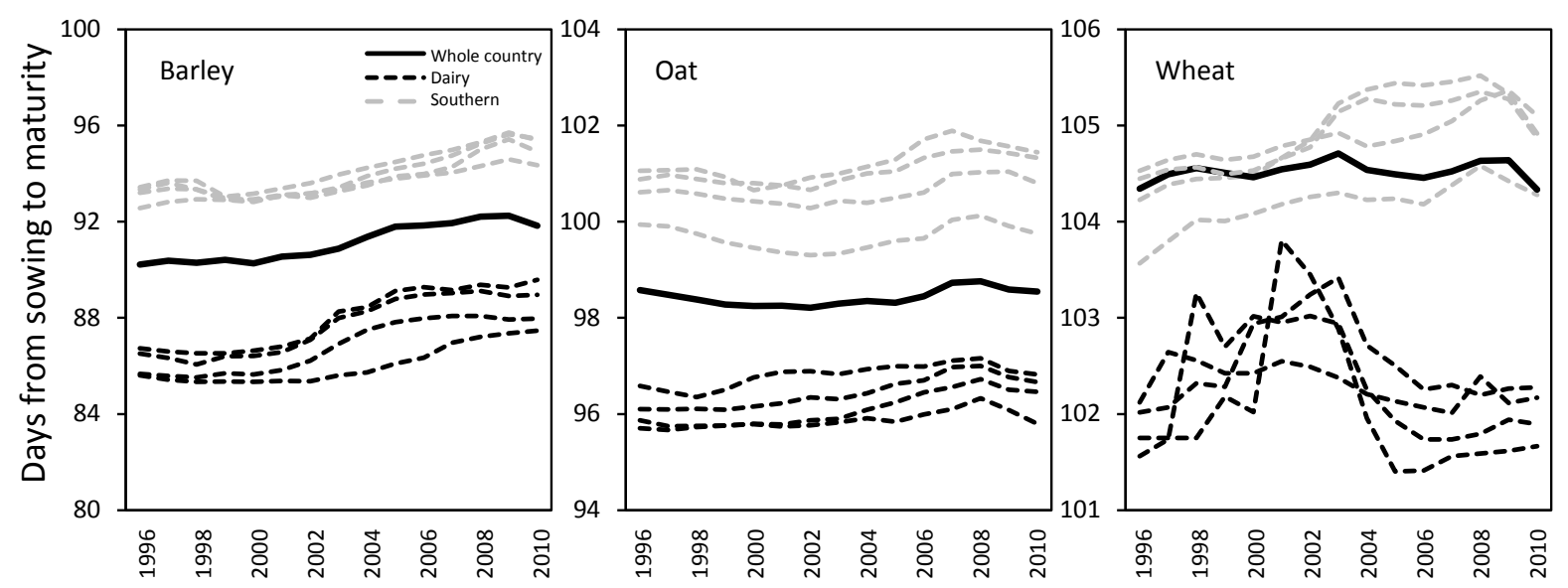

Fig. 5. Shifts in use of later maturing cultivars of barley and wheat, and lack of trends in oat, when averaged across all regions and for north-central and southern regions. Similar line types indicate sub-regions within southern and dairy regions.

Cereal yields in the north-central region were lower than in the southern region, the prime cereal production region in Finland (Fig. 6). An earlier comprehensive study on yield differences and variation in Finland also showed regional differences in production, i.e. cereals in the most northern and eastern regions had lower yields than those in southern and western Finland (Himanen et al. 2012). Our results indicated that variation among years was, however, wider in the southern region, especially for barley and oat. Typically oat is not, in contrast to wheat, grown in the most favorable fields of the southern regions, which partly explains the high yield variability. In addition, oat can suffer from early summer drought, especially as it is often sown later than other crops, particularly wheat. Higher variation in wheat yields in the northern region compared with barley and oat is attributable to the longer growing season requirement of wheat and the corresponding higher risk for not coming to maturity at harvest time.

When assessing shifts in cropping areas for barley, oat and wheat at the national scale, we did not find significant associations with previous weather conditions. The only exception was that a prolongation in growing time from sowing to yellow ripeness experienced in a preceding year associated to a decreased cultivation area of spring wheat in the following year (Fig. 7a). This was only a moderate signal and only evident for wheat, probably because farmers may have incentives to increase wheat areas when the relative return on higher-yielding species or cultivars increases despite associated higher risks for crop failures due to later maturity (Peltonen-Sainio and Niemi 2012). In another recent study a positive correlation was established between yield of barley and wheat in the preceding five year period and the cultivation area of the same crop in the following year, which suggests encouragement of continuous cultivation of a crop that has proven reliable in the long run while rejecting species posing higher risks for yield losses (Himanen et al. 2012). 


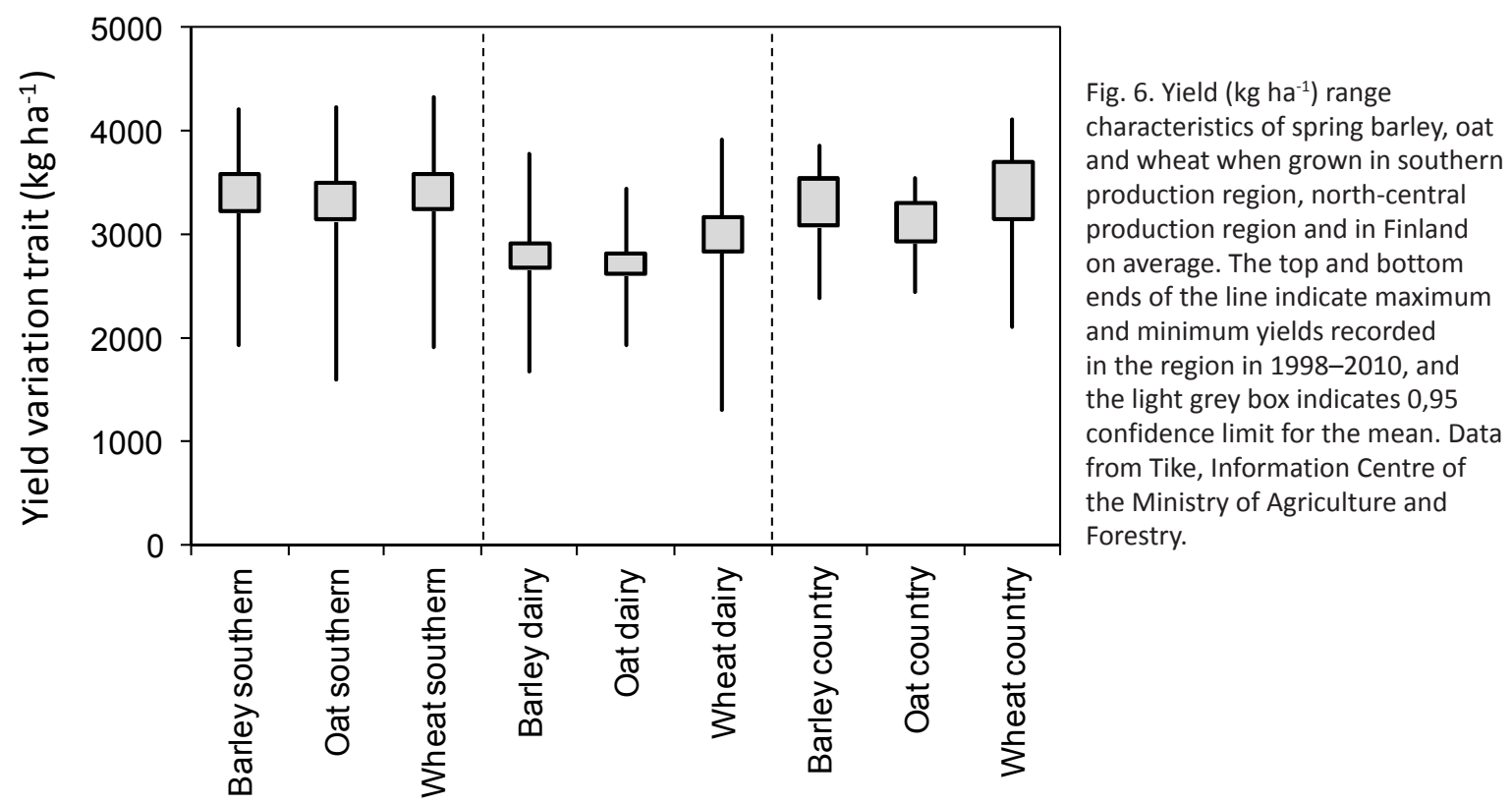

We found regional differences in farmer response to experienced conditions (Fig 7b-e). Regional assessment indicated that in the north-central production region, farmers were not apt to change field use after having faced challenges in previous years. Also in the study of Himanen et al. (2012) in northern and north-eastern areas farmers were less ready to change crop species compared with those in the southern regions. The minor role of wheat in northern regions (Fig. 1) partly explains the lack of response as barley and oat are, in practice, the only alternative cereal crops that can produce consistently high yields. Furthermore, dependence on both grass silage and cereal grain for cattle feed in the north-central region per se guides field use and limits farmers' possibilities to speculate with crop choice according to experienced conditions and changing markets. In particular, cattle farms need to allocate a large proportion of their land to grass because there are no markets for large-scale trade of silage. Moreover, we found that farmers in the north-central regions tended to respond to favorable temperature conditions in the preceding year by shifting to slightly later maturing, higher yielding oat cultivars, which was especially true in the case when maturity occurred exceptionally early in the preceding year $(r=-0.48, p=0.08)$. Farmers in the north-central production region are associated with the highest rate of use of commercial certified seed (Peltonen-Sainio and Rajala 2013), which again makes a shift from early to late maturing cultivars or vice versa a more viable option. Even though general use rates of commercial certified seed are particularly low for oat in Finland (Peltonen-Sainio and Rajala 2013), it was not only in the dairy-oriented region but across the whole country that farmers tended to use late maturing oat cultivars if maturity occurred earlier in the previous year ( $r=$ $-0.47, p=0.09)$ or the accumulated temperature sum in the preceding year was higher than usual $(r=0.45, p=0.11)$.

The three spring cereals studied here are all major crops in the southern region (Fig. 1), and we established associations between growing season, weather conditions and land use. For example, increase in late summer precipitation in the preceding year (generally represented as a challenge to harvests of late maturing crops) coincided with increased area of spring barley cultivation in the following year (Fig. 7b) and use of wheat cultivars that matured slightly earlier ( $r=-0.54, p=0.05)$. Furthermore, farmers tended to increase barley cultivation (Fig.7c) while reducing wheat area (Fig. 7d) in the case of a previous year being associated with a higher number of days from sowing to yellow ripeness. Farmer readiness to give up barley took place when cumulated degree days for the growing season in a preceding year were higher (Fig. 7e). Availability of commercial certified seed for requested cultivars limits farmer possibilities to realize plans for switching cultivars or crops in some years. Our examples suggest that farmers in the northernmost cereal cropping areas have potential to respond promptly to changed opportunities in optimization of land use induced by climate warming, but the extent depends on the comparative advantages of current and future novel crop species (Elsgaard et al. 2012). According to market studies (OECD-FAO 2011, FAPRI 2011), the output prices of cereals are expected to increase. This may highlight the importance of stable yield, which may lead producers to prefer high-yields and robust cultivars. In addition, the volatility of the agricultural commodity market is expected to continue to increase in the future (Cooke and Robles 2009). This could have a minor impact on cultivar choice, although it is difficult to anticipate which cultivars would be the most profitable. 


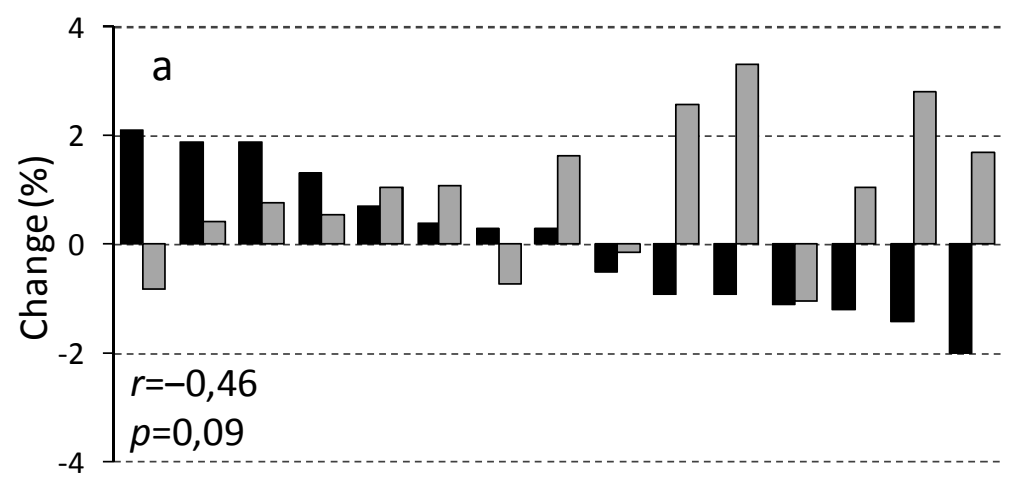

Years in order of change in growing time
Fig. 7a. Coincidence of changes in growing time from sowing to yellow ripeness in the preceding year (black bar) and changes in cultivation area of spring wheat (\% unit increase or decrease) in the following year (grey bar) when calculated across the whole of Finland. Data for 1996-2010 from Tike, Information Centre of the Ministry of Agriculture and Forestry.

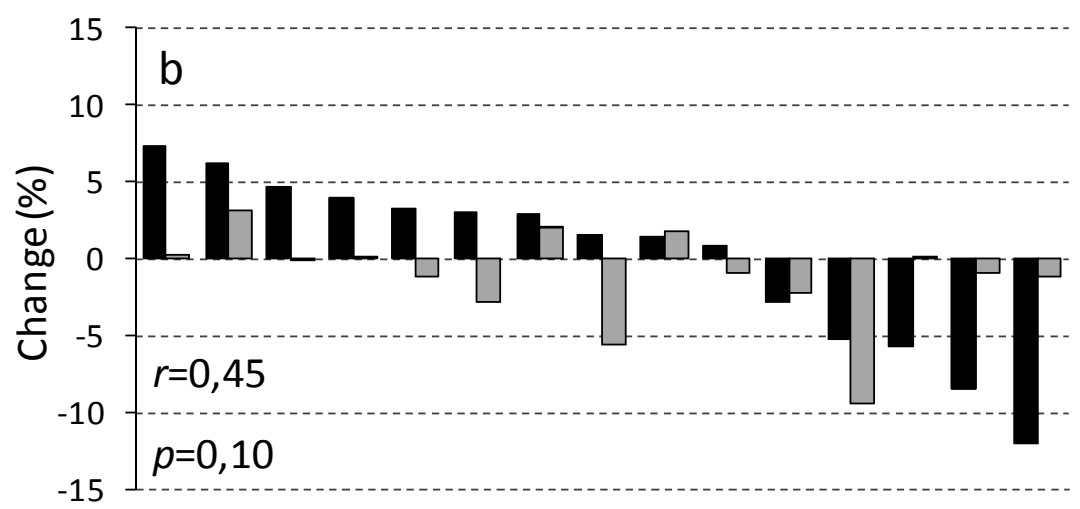

Years in order of change in precipiation

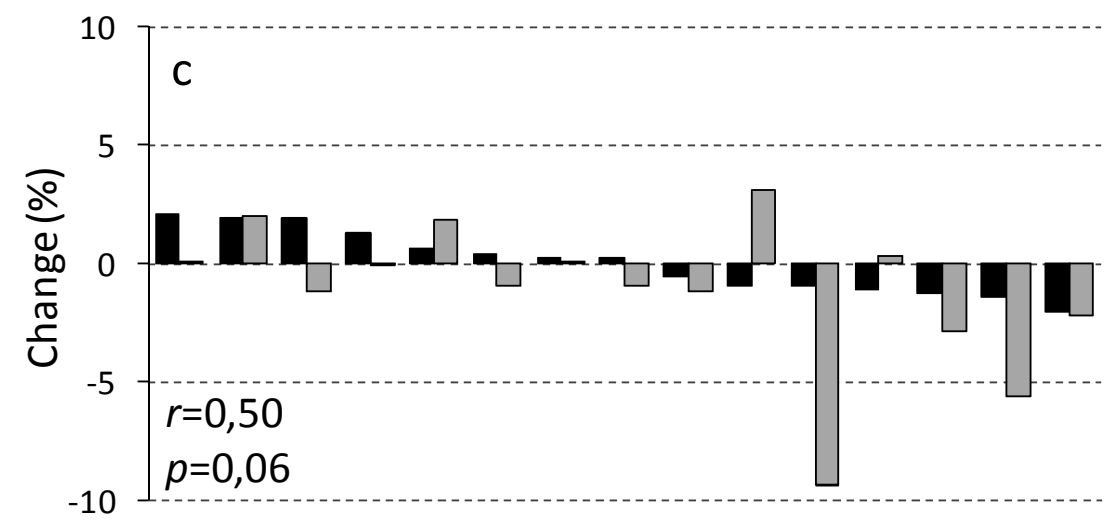

Years in order of change in growing time
Fig. 7c. Coincidence of changes in growing time from sowing to yellow ripeness in the preceding year (black bar) and changes in cultivation area of spring barley (\% unit increase or decrease) in the following year (grey bar) in southern Finland. 


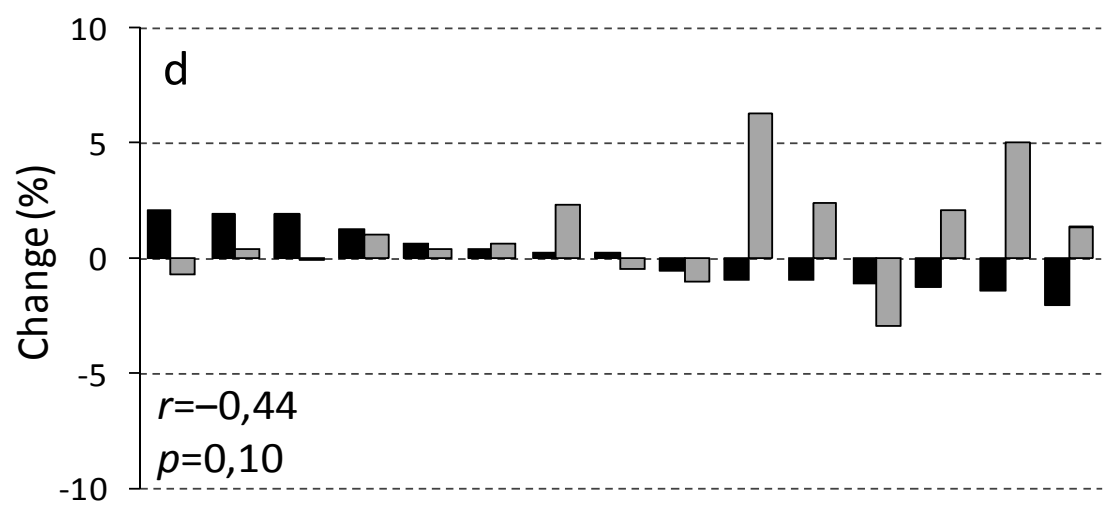

Years in order of change in growing time
Fig. 7d. Coincidence of changes in growing time from sowing to yellow ripeness in the preceding year (black bar) and changes in cultivation area of spring wheat $(\%$ unit increase or decrease) in the following year (grey bar) in southern Finland.

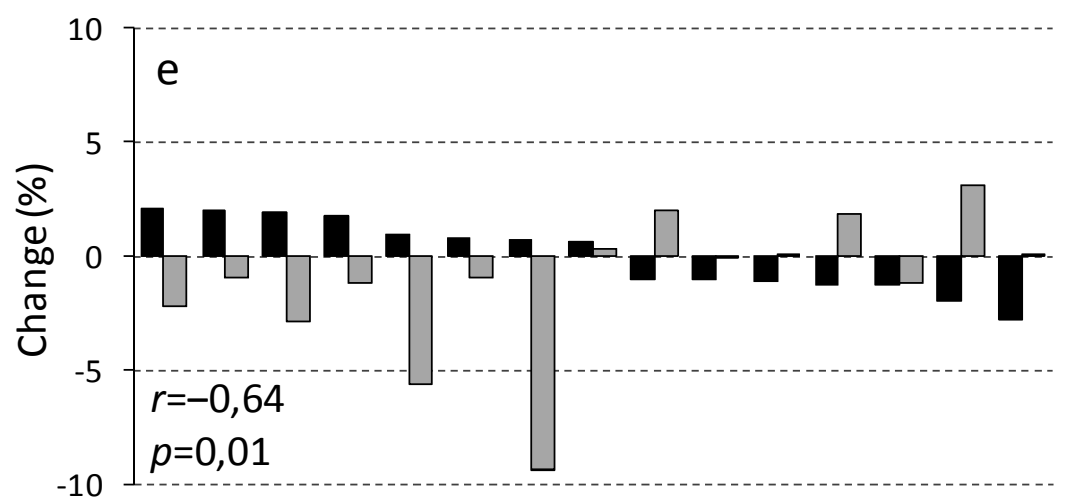

Years in order of change in cumulated degree days
Fig. 7e. Coincidence of changes in cumulated degree days from the beginning of the thermal growing season to 4 September in the preceding year (black bar) and changes in cultivation area of spring barley (\% unit increase or decrease) in the following year (grey bar) in southern Finland.

All the examples provided emphasize that farmers were ready to benefit from an even slightly prolonged growing season by choosing later maturing cultivars and wheat instead of barley. This indicates that farmers can rapidly adapt to warmer growing seasons induced by climate change in northern Europe. However, we did not establish an association between changes in producer prices and cultivar choice. This may be because price changes were similar for different cultivars during the study period. Changes in prices did not explain trends according to which wheat cultivation is favored at the expense of barley and oat because since 2005 the price of barley has developed more favorably than that of wheat. This may be because price is not the only important parameter. The economics of cultivation depend on relative prices. Adding more price parameters and subsidy rates to the analysis might provide greater insight. For instance, subsidy rates around the millennium were differentiated by crop. In addition price changes were modest around the millennium. Gross margins might therefore usefully indicate which crops farmers prefer to cultivate.

In conclusion, this study indicated that farmers analyze their earlier experiences of weather events in a preceding growing season and use this information to decide on crop and cultivar to be sown during the next season, especially regarding switching between cultivation of early maturing barley and later maturing wheat. Interestingly this was true for this northernmost European growing region where the short growing season is the major limitation for yield formation and where there are very limited numbers of alternative crops. Our results indicate that due to continuous observations of growing conditions and basing decision making on experiences, farmers are also likely to be better prepared to meet the opportunities and challenges brought by climate change. We did not, however, find that during the 15 year study period prices of grain and inputs would have markedly contributed to farmer decision making on land use. This may be because of stable grain prices over the period. If there is little price volatility, there are only a few cases where changes in cultivation would be possible. In addition, subsidies may have directed cultivation towards particular crops, and hence the incentive to switch crops is reduced. 


\section{Acknowledgements}

The work was financed by the Finnish Ministry of Agriculture and Forestry and research partner institutes as a part of an on-going consortium project entitled Strengthening domestic protein self-sufficiency under the pressure of global changes (OMAVARA).

\section{References}

Cooke, B. \& Robles, M. 2009. Recent Food Prices Movements: A Time Series Analysis. IFPRI Discussion Paper No.00942. Cited 25 November 2012. Available on the Internet: http://www.ifpri.org/sites/default/files/publications/ifpridp00942.pdf

Elsgaard, I., Børgesen, C.D., Olesen, J.E., Siebert, S., Ewert, F., Peltonen-Sainio, P., Rötter, R. \& Skjelvåg, A. 2012. Shifts in comparative advantages for maize, oat and wheat cropping under climate change in Europe. Food Additives and Contaminants, Part A 29: 1514-1526.

FAPRI 2011. FAPRI-ISU 2011 world agricultural outlook database. Cited 25 November 2012. Available on the Internet: http:// www.fapri.iastate.edu/tools/outlook.aspx

Hakala, K., Jauhiainen, L., Himanen, S.J., Rötter, R., Salo, T. \& Kahiluoto, H. 2012. Sensitivity of barley varieties to weather in Finland. Journal of Agricultural Science 150: 145-160.

Himanen, S.J., Hakala, K. \& Kahiluoto, H. 2012. Crop responses to climate and socioeconomic change in northern regions. Regional Environmental Change14: 36-37.

Kangas, A., Laine, A., Niskanen, M., Salo, Y., Vuorinen, M., Jauhiainen, L. \& Nikander, H. 2010. Results of official variety trials 2003-2010. MTT Kasvu 13, 174 p. Cited 10 November 2012). Available on the Internet: www.mtt.fi/mttkasvu/pdf/mttkasvu13. pdf . Partly in English.

Kaukoranta, T. \& Hakala, K. 2008. Impact of spring warming on sowing times of cereal, potato and sugar beet in Finland. Agricultural and Food Science 17: 165-176.

Lobell, D.B., Cahill, K.N. \& Field, C.B. 2007. Historical effects of temperature and precipitation on California crop yields. Climatic Change 81: 187-203.

Lobell, D.B. \& Field, C.B. 2007. Global scale climate-crop yield relationships and the impacts of recent warming. Environmental Research Letters 2: 1-7.

Mukula, J. \& Rantanen, O. 1987. Climatic risks to the yield and quality of field crops in Finland. I. Basic facts about Finnish field crops production. Annals of Agriculturae Fennica 26: 1-18.

OECD-FAO 2011. OECD-FAO Agricultural Outlook 2011-2020. OECD, Paris. Cited 25 November 2012.Available on the Internet: http://www.agri-outlook.org

Official Statistics of Finland 2012a. Index of producer prices of agricultural products (e-publication). Statistics of Finland, Helsinki. Cited 20 April 2012. Available on the Internet: http://www.tilastokeskus.fi/til/mthi/index_en.html

Official Statistics of Finland 2012b. Index of purchase prices of the means of agricultural production (e-publication). Statistics of Finland, Helsinki. Cited 20 April 2012. Available on the Internet: http://www.tilastokeskus.fi/til/ttohi/tau_en.html

Peltonen-Sainio, P., Hakala, K. \& Jauhiainen, L. 2011a. Climate induced overwintering challenges for wheat and rye in northern agriculture. Acta Agriculturae Scandinavica, B Soil and Plant Science 61: 75-83.

Peltonen-Sainio, P., Jauhiainen, L. \& Hakala, K. 2009b. Are there indications of climate change induced increases in variability of major field crops in the northernmost European conditions? Agricultural and Food Science 18: 206-226.

Peltonen-Sainio, P., Jauhiainen, L. \& Hakala, K. 2011b. Crop responses to temperature and precipitation according to long-term multi-location trials at high-latitude conditions. Journal of Agricultural Science 149: 49-62.

Peltonen-Sainio, P., Jauhiainen, L., Hakala, K. \& Ojanen, H. 2009d. Climate change and prolongation of growing season: changes in regional potential for field crop production in Finland. Agricultural and Food Science 18: 171-190.

Peltonen-Sainio, P., Jauhiainen, L., Trnka, M., Olesen, J.E., Calanca, P.L., Eckersten, H., Eitzinger, J., Gobin, A., Kersebaum, C., Kozyra, J., Kumar, S., Marta, A.D., Micale, F., Schaap, B., Seguin, B., Skjelvåg, A.O. \& Orlandini, S. 2010. Coincidence of variation in yield and climate in Europe. Agriculture, Ecosystems and Environment 139: 483-489.

Peltonen-Sainio, P., Jauhiainen, L. \& Venäläinen, A. 2009c. Comparing regional risks in producing turnip rape and oilseed rape Today in light of long-term datasets. Acta Agriculturae Scandinavica, B Soil and Plant Science 59: 118-128.

Peltonen-Sainio, P. \& Niemi, J.K. 2012. Protein crop production at the northern margin of farming: To Boost, or not to boost. Agricultural and Food Science 21: 370-383.

Peltonen-Sainio, P. \& Rajala, A. 2007. Duration of vegetative and generative development phases in oat cultivars released since 1921. Field Crops Research 101: 72-79.

Peltonen-Sainio, P. \& Rajala, A. 2013. Use of quality seed as a basic means to sustainably intensify northern European barley production. Journal of Agricultural Science, doi:10.1017/S0021859612000962.

Peltonen-Sainio, P., Rajala, A., Känkänen, H. \& Hakala, K., 2009a. Improving farming systems in northern European conditions. In: Sadras, V.O. \& Calderini, D. (eds). Crop Physiology: Applications for Genetic Improvement and Agronomy. Amsterdam, The Netherlands: Elsevier. p. 71-97. 
Reidsma, P., Ewert, F., Lansink, A.O. \& Leemans, R. 2010. Adaptation to climate change and climate variability in European agriculture: The importance of farm level responses. European Journal of Agronomy 32: 91-102.

Rötter, R.P., Palosuo, T., Pirttioja, N.K., Dubrovski, M., Salo, T., Fronzek, S., Aikasalo, R., Trnka, M., Ristolainen, A. \& Carter, T.R. 2011. What would happen to barley production in Finland if global warming exceeded $4{ }^{\circ} \mathrm{C}$ ? A model-based assessment. European Journal of Agronomy 35: 205-214.

Trnka, M., Olesen, J.E., Kersebaum, K.C., Skjelvåg, A.O., Eitzinger, J., Seguin, B., Peltonen-Sainio, P., Rötter, R., Iglesias, A., Orlandini, S., Dubrovský, M., Hlavinka, P., Balek, J., Eckersten, H., Cloppet, E., Calanca, P., Gobin, A., Vucetic V., Nejedlik, P., Kumar, S., Lalic, B., Mestre, A., Rossi, F., Kozyra, J., Alexamdrov, V., Semerádová, D. \& Zalud, Z. 2011. Agroclimatic conditions in Europe under climate change. Global Change Biology 17: 2298-2318.

Zadoks, J.C., Chang, T.T. \& Konzak, C.F. 1974. A decimal code for the growth stages of cereals. Weed Research 14: 415-421. 